\title{
DISPARITAS FISKAL ANTARDAERAH DI PROVINSI JAWA TENGAH *
}

\author{
Jaka Sriyana \\ Fakultas Ekonomi, Universitas Islam Indonesia, Yogyakarta \\ Condong catur, Depok, Sleman, Yogyakarta 55283, Indonesia Telepon : +62-274-881546 \\ E-mail: jakasriyana@fe.uii.ac.id
}

\section{Diterima 29 Desember 2010/Disetujui 15 Mei 2011}

\begin{abstract}
Local fiscal capacity plays a crucial role in the implementation of regional development. This study aims to examine the fiscal disparities among regions in Central Java province in 2007-2009 period. The research method used is the average difference test against various classes/groups of local fiscal variables, namely level of independence and the degree to fiscal dependency. From the results of the analysis, indicate a significant disparity between the city/county. For the analysis of disparities in fiscal independence, indicate a disparity of high and relatively constant. As for the analysis of disparities in fiscal dependence, indicate a relatively low disparities between city/county. These results imply that the city and district in Central Java province has continued in fiscal independence vary widely but tend to have nearly the same fiscal dependency. This condition will affect the low level of local government discretion in planning and execution of development in the region.
\end{abstract}

Keywords: fiscal capacity, fiscal dependency, fiscal disparities, regional development

\begin{abstract}
Abstrak: Kemampuan fiskal daerah memainkan peranan yang sangat penting dalam pelaksanaan pembangunan daerah. Penelitian ini bertujuan untuk mengkaji perbedaan/ disparitas fiskal antardaerah di Provinsi Jawa Tengah pada periode 2007-2009. Metode yang digunakan adalah uji beda rata terhadap berbagai kelas/kelompok variabel fiskal daerah, yaitu tingkat kemandirian dan tingat ketergantungan fiskal. Dari hasil analisis menunjukkan adanya disparitas yang cukup besar antarkota/kabupaten. Untuk analisis disparitas kemandirian fiskal menunjukkan adanya disparitas yang tinggi dan cenderung konstan selama tiga tahun yang diamati. Adapun untuk analisis disparitas ketergantungan fiskal menunjukkan adanya disparitas yang relatif rendah antarkota/kabupaten selama tiga tahun yang diamati. Hasil ini memberikan implikasi bahwa kota dan kabupaten di provinsi Jawa Tengah secara terus menerus memiliki kemandirian fiskal yang sangat bervariasi namun cenderung memiliki ketergantungan fiskal yang hampir sama. Kondisi ini akan berdampak pada rendahnya diskresi pemerintah daerah dalam menyusun perencanaan dan pelaksanaan pembangunan di daerah.
\end{abstract}

Kata kunci: kemampuan fiskal, ketergantungan fiskal, disparitas fiskal, pembangunan daerah

\section{PENDAHULUAN}

Perkembangan tata kelola pembangunan daerah dalam sepuluh tahun terakhir di Indonesia telah ditandai dengan perubahan mendasar pa-

\footnotetext{
* Penelitian ini terlaksana atas biaya dari skim Penelitian Strategis Nasional, Direktorat Penelitian dan Pengabdian Masyarakat (DP2M), Direktorat Jenderal Pendidikan Tinggi, Kementerian Pendidikan Nasional Tahun 2010.
}

da dua aspek, yaitu aspek politik dan aspek ekonomi. Pada aspek politik tercermin pada semakin kuatnya kewenangan daerah dalam menentukan berbagai kebijakan di daerah, sedangkan dimensi ekonomi ditandai dengan adanya kebijakan transfer fiskal dari pemerintah pusat kepada pemerintah daerah yang semakin besar. Dua hal tersebut merupakan konsekuensi dari diberlakukannya UU 32/2004 
dan UU 33/2004, yang pada dasarnya bertujuan untuk memperkecil ketimpangan keuangan antara pemerintah pusat dan pemerintah daerah (vertical imbalance), mengoreksi ketimpangan antardaerah dalam kemampuan keuangan (horizontal imbalance), dan meningkatkan kualitas pelayanan kepada masyarakat, serta meningkatkan partisipasi masyarakat dalam pengambilan keputusan di sektor publik.

Desentralisasi pada dasarnya adalah penataan mekanisme pengelolaan kebijakan dengan kewenangan yang lebih besar diberikan kepada daerah agar penyelenggaraan pemerintahan dan pelaksanaan pembangunan lebih efektif dan efisien. Pemerintah daerah dianggap lebih mengetahui kebutuhan dan kondisi daerahnya, serta keinginan masyarakat di daerah masingmasing dibandingkan pemerintah pusat. Pemerintah daerah juga diharapkan dapat merealisasikan pendapatan yang mereka terima dengan membelanjakan dana tersebut sesuai dengan kebutuhan masyarakat di daerah masingmasing. Desentralisasi juga merupakan pelimpahan sebagian wewenang dan pertanggungjawaban yang diikuti dengan pemberian wewenang untuk mengelola sumber-sumber keuangan untuk membiayai kegiatan operasional dan penyediaan pelayanan publik (public service). Pelimpahan wewenang tersebut berkaitan dengan fungsi-fungsi manajemen urusan pemerintahan dan bidang keuangan pemerintah daerah (local government financial management) dari pemerintah pusat kepada pemerintahan daerah.

Evaluasi terhadap pelaksanaan otonomi daerah di Indonesia sejauh ini telah banyak dilakukan oleh beberapa ahli ekonomi yaitu Haris (2005), Salam (2005), Hofman, et.al., (2006) dan Nasara (2010). Haris (2005) dan Salam (2005) menemukan adanya berbagai masalah yang muncul dalam pelaksanaan otonomi daerah, yaitu masih dominannya faktor nonekonomi dalam penentuan dana transfer, belum terciptanya pemerataan alokasi dana transfer kepada daerah, terciptanya disparitas kapasitas fiskal antara kota dan kabupaten. Mengingat bahwa dana transfer merupakan porsi terbesar dari pendapatan daerah, maka besaran dana tersebut akan sangat menentukan capaian hasil pembangunan.
Hoftman et al. (2006) dalam evaluasinya terhadap kebijakan transfer fiskal di Indonesia menjelaskan bahwa pelaksanaan tranfer fiskal dalam bentuk block grant (DAU) belum mampu mencapai tujuan utamanya, yaitu menciptakan pemerataan kapasitas fiskal antardaerah sehingga akan berdampak pada tercapainya kinerja pembangunan di daerah. Hal ini disebabkan oleh: Pertama, adanya faktor politik yang sangat dominan dalam penentuan transfer fiskal; Kedua, besaran dana transfer tidak mampu mengatasi kebutuhan belanja daerah (fiscal needs). Namun demikian dana transfer dari pemerintah pusat belum mampu meningkatkan belanja untuk pembangunan dan pelayanan publik secara signifikan. Bahkan dana dari pemerintah pusat juga belum mampu meningkatkan pemerataan kemampuan keuangan daerah di kota maupun kabupaten.

Menurut Nasara (2010), saat ini telah terjadi berbagai macam ketimpangan hasil pembangunan antardaerah yang dapat dilihat dari berbagai indikator ekonomi, misalnya distribusi pendapatan antardaerah (PDRB), kesempatan kerja, Indek Pembangunan Manusia (IPM), pendidikan, dan kesehatan. Kondisi ini merupakan akibat dari kemampuan fiskal antardaerah yang sangat berbeda yang tidak mampu diatasi oleh dana transfer. Perubahan kewenangan politik di daerah secara signifikan, namun belum mampu membawa perubahan kewenangan menggali sumber daya keuangan secara mandiri oleh daerah. Selama sepuluh tahun pelaksanaan otonomi daerah masih ditandai dengan rendahnya kapasitas fiskal daerah dan munculnya disparitas kapasitas fiskal antarkota/kabupaten, maupun antara kota dan kabupaten yang sangat mencolok.

Perbedaan tersebut akan semakin jelas jika diperbandingkan antara kemampuan fiskal kota dan kabupaten. Antara kota dan kabupaten memiliki perbedaan mendasar dalam dua hal, yaitu kapasitas fiskal serta kemampuan pelayanan publik. Kota merupakan daerah yang memiliki kapasitas fiskal dan kemampuan layanan publik tinggi, sedangkan kabupaten, apalagi kabupaten hasil pemekaran memiliki kapasitas fiskal dan kemampuan pelayanan publik yang rendah. Namun keduanya terikat oleh fungsi utamanya sebagai public services 
seperti tercantum dalam UU tentang Standar Pelayanan Minimum (SPM) sebagai ukuran minimal dalam pelayanan publik.

Fenomena tersebut tentu membawa akibat pada terjadinya perbedaan kinerja pembangunan maupun kinerja birokrasi yang berujung pada tidak tercapainya standar minimal pelayanan publik sebagaimana diamanatkan dalam berbagai peraturan pemerintah sejak tahun 2005. Salah satu faktor penyebabnya adalah pelaksanaan transfer fiskal kepada daerah yang tidak mengakomodasi permasalahan aktual di daerah. Selama ini pelaksanaan transfer fiskal justru lebih didominasi oleh faktor politik dengan pertimbangan kepentingan dari sudut pandang pemerintah pusat.

Faktor disparitas kapasitas fiskal antardaerah kota dan kabupaten merupakan salah satu variabel penentu transfer fiskal. Antara daerah kota dan kabupaten memiliki perbedaan mendasar dalam dua hal, yaitu kapasitas fiskal dan serta kemampuan pelayanan publik. Daerah tertentu dapat merupakan daerah yang memiliki kapasaitas fiskal dan kemampuan layanan publik tinggi, sedangkan kabupaten atau kota lain, apalagi kabupaten hasil pemekaran memiliki kapasitas fiskal dan kemampuan pelayanan publik yang rendah. Namun keduanya terikat oleh fungsi utamanya sebagai public services seperti tercantum dalam UU tentang Standar Pelayanan Minimum (SPM) sebagai ukuran minimal dalam pelayanan publik. Oleh karena itu, perlu suatu kajian yang mendalam tentang berbagai aspek yang melingkupi serta efek dari adanya disparitas fiskal daerah tersebut.

Pengelolaan fiskal merupakan aspek penting dalam mendorong perekonomian suatu daerah kota/kabupaten. Kondisi fiskal yang tercermin di dalam anggaran pemerintah yang baik, kuat, dan memiliki ketahanan (strength), serta kesinambungan (sustainability) yang baik akan semakin mendukung kinerja perekonomian daerah secara berkelanjutan. Tata kelola fiskal daerah memiliki berbagai tujuan dalam mengarahkan aktivitas ekonomi regional, yaitu peningkatan pertumbuhan ekonomi, stabilisasi harga, pemerataan distribusi pendapatan, dan peningkatan kesempatan kerja (Ahmed dan Kenneth, 2000; Hondroyiannis dan Papapetrue, 2001).
Sebagai konsekuensi dari kebutuhan belanja dan keterbatasasn penerimaan pemerintah daerah, hampir semua pemerintah daerah mengalami defisit anggaran. Sejalan dengan defisit fiskal tersebut ternyata dapat memberikan dampak kepada peningkatan pengeluaran pemerintah. Kondisi defisit fiskal yang dialami pemerintah dan peningkatan pengeluaran pemerintah tersebut akan berdampak pada nilai besaran variabel makro ekonomi daerah. Masalah berikut yang muncul adalah adanya efisiensi perekonomian yang rendah, termasuk pula efisiensi pengelolaan keuangan negara serta terjadinya ancaman terhadap penerimaan daerah. Jika kondisi ini terjadi dalam jangka panjang akan dapat mengancam kesinambungan fiskal pada masing-masing daerah.

Berbagai kajian terkait dengan kapasitas dan tata kelola fiskal daerah telah banyak dilakukan oleh para peneliti sebelumnya (Kurnia, 2005; Sebayang, 2005; Pertiwi, 2006). Kurnia (2005) menemukan bahwa efisiensi fiskal dalam pengeluaran belanja pemerintah daerah dipengaruhi oleh kesesuaian pengeluaran belanja dengan preferensi masyarakat. Dalam kaitannya dengan desentralisasi fiskal, efisiensi alokasi bisa karena sumber daya yang ada dialokasikan di antara berbagai jenis pengeluaran belanja yang sesuai dengan preferensi masyarakat daerah. Pengukuran efisiensi alokasi ini tidak bisa dilakukan secara langsung karena ukuran preferensi marginal masyarakat sulit untuk diketahui. Efisiensi fiskal menyangkut pula aspek sumber penerimaan pemerintah daerah untuk membiayai pengeluaran belanja pemerintah daerah.

Efisiensi fiskal dalam kaitannya dengan sumber penerimaan ini ditentukan oleh tiga hal: (1) Apakah pajak dan retribusi daerah yang dipungut merupakan pajak yang tepat dalam artian bahwa pajak dan retribusi daerah yang dipungut dari objek pajak tertentu langsung terkait dengan target-target pengeluaran tertentu pula; (2) Dana perimbangan (transfer pemerintah pusat) seharusnya ditujukan untuk penyesuaian-penyesuaian karena adanya eksternalitas tanpa mengganggu kepentingan pemerintah daerah; (3) Anggaran Pendapatan dan Belanja Daerah (APBD) seharusnya tidak menyebabkan tekanan dan dampak negatif terha- 
dap stabilitas ekonomi regional. Tinggi rendahnya efisiensi pengelolaan fiskal akan berdampak pada tingkat kapasitas fiskal daerah sehingga akan menimbulkan perbedaan kapasitas fiskal antardaerah tersebut.

Berdasarkan analisisnya tentang kinerja fiskal daerah pascakrisis ekonomi 1997, Sebayang (2005) menyimpulkan terjadinya disparitas kapasitas fiskal antarprovinsi di Indonesia yang sangat signifikan. Pengukuran kinerja kebijakan fiskal daerah pada studi ini menggunakan lima variabel (DAU, Belanja Rutin, Pengeluaran untuk Transportasi, Pajak, dan Retribusi). Wilayah yang diamati mencakup 26 provinsi pada empat periode (1999-2002), dan melibatkan banyak wilayah yang mempunyai kapasitas yang berbeda, khususnya perbedaan kapasitas fiskal. Dari hasill studi tersebut juga ditemukan bahwa kinerja kebijakan fiskal memiliki ciri yang spesifik. Pada sektor publik mengatasi sumber inefisiensi tidak bisa sefleksibel sektor swasta. Banyak variabel sudah bersifat "given", misalnya anggaran daerah biasanya sudah tertentu dan sulit diintervensi.

Kajian tersebut juga memberikan kesimpulan bahwa kapasitas fiskal daerah di Indonesia sangat bervariasi bahkan cenderung menunjukkan adanya kesenjangan kapasitas fiskal antardaerah. Kesenjangan pencapaian efisiensi kebijakan fiskal ini juga merupakan gambaran kesenjangan kemampuan pengelolaan keuangan daerah dan kesenjangan sumber daya wilayah. Ini dapat dilihat dari identifikasi sumber inefisiensi di masing-masing wilayah yang cukup beragam. Ada wilayah yang inefisien pada variabel input, namun banyak pula yang inefisiensi pada variabel output. Wilayah yang mampu membiayai belanja rutin bersumber dari PAD hanya Jawa Timur dan Bali. Kondisi ini cukup mengkhawatirkan sehingga diperlukan upaya lebih lanjut agar daerah mampu "membiayai" pengeluarannya. Dari perhitungan kinerja kebijakan fiskal menunjukkan adanya variasi bobot kinerja yang tinggi. Terdapat dua wilayah yang konsisten mencapai efisiensi tertinggi pada pungutan yakni DKI Jakarta dan Jawa Timur. Kedua daerah ini kemudian bisa mencapai referensi bagi daerah lain untuk peningkatan kinerja kebijakan fiskalnya dan mampu mencapai 100 persen efisiensi selama empat periode.

Pertiwi (2006), mengadakan penelitian tentang tingkat efisiensi pengeluaran pemerintah daerah kabupaten/kota di Jawa Tengahdi sektor pendidikan dan kesehatan. Dengan tujuan untuk menganalisis besarnya tingkat efisiensi pengeluaran pemerintah daerah kabupaten/ kota di Jawa Tengah pada sektor pendidikan dan kesehatan. Metode yang digunakan pada analisis ini adalah menggunakan pendekatan nonparametrik Data Envelopment Analysis (DEA) dengan menggunakan data 35 kabupaten/kota di Jawa Tengah pada tahun 1999 dan 2002. Analisis ini dimaksudkan untuk pengukuran efisiensi belanja daerah yang melibatkan banyak input dan banyak output (multi-input multi-output). Berdasarkan hasil analisis menunjukkan bahwa tingkat efisiensi pengeluaran pemerintah daerah pada tahun 1999 di setiap kabupaten/kota di Jawa Tengahcenderung belum efisien.

Provinsi Jawa Tengah merupakan salah satu provinsi yang memiliki jumlah kota dan kabupaten relatif banyak, yaitu 35 daerah. Berdasarkan data-data perkembangan penerimaan daerah maupun transfer fiskal yang diterima masing-masing daerah menunjukkan adanya perbedaan yang relatif besar. Kondisi ini dapat diduga akan melahirkan perbedaan/disparitas kapasitas fiskal maupun ketergantungan fiskal yang relatif besar sehingga akan mengasilkan capaian pembangunan daerah yang berbeda pula. Penelitian ini bertujuan untuk menganalisis berbagai aspek berkaitan dengan disparitas fiskal antarkota/kabupaten di provinsi tersebut.

\section{METODE PENELITIAN}

\section{Data dan Sumbernya}

Data yang dianalisis dalam penelitian ini adalah data-data yang menunjukkan indikator fiskal daerah, yaitu Kemandirian Fiskal (KMF) yang diperoleh dari rasio Pendapatan Asli Daerah (PAD) terhadap belanja total dan Ketergantungan Fiskal (KTF) yang diperoleh dari rasio Dana Alokasi Umum (DAU) terhadap total belanja. Data-data yang digunakan diambil dari Laporan Statistik Keuangan Dae- 
rah terbitan Biro Pusat Statistik Jakarta untuk periode 2007-2009.

\section{Metode Analisis}

Analisis disparitas kapasitas fiskal antarkota/ kabupaten dapat dilakukan dengan dua metode, yaitu dengan metode uji beda rata-rata (UBR). Metode UBR berguna untuk mengetahui tingkat perbedaan rata-rata variabel fiskal antara kota dengan kabupaten berdasarkan pembedaan kelompok. Pada penelitian ini variabel fiskal yang dianalisis adalah kemandirian fiskal (KMF) dan ketergantungan fiskal (KTF). Kemandirian fiskal menunjukkan kemampuan daerah membiayai dari sumber pendapatannya sendiri, sedangkan ketergantungan fiskal menunjukkan kebutuhan transfer fiskal dari pemerintah pusat untuk membiayai belanja daerah. Untuk mengetahui disparitas fiskal antarkota/ kabupaten dengan uji beda rata-rata (UBR) terhadap variabel indikator fiskal dengan menguji perbedaan rata berdasarkan pengelompokan data sesuai dengan urutan besaran variabel masing-masing variabel fiskal, yaitu KMF dan KTF. Dalam penelitian ini dilakukan pengelompokan dan uji sebagai berikut (Tabel 1).

Tabel 1. Prosedur Uji Beda Rata-Rata pada Variabel Fiskal

\begin{tabular}{ccc}
\hline $\begin{array}{c}\text { Kelompok } \\
\text { (A) }\end{array}$ & $\begin{array}{c}\text { Diuji terhadap } \\
\text { Kelompok (B) }\end{array}$ & $\begin{array}{c}\text { Hipotesis Nul } \\
\text { (Ho) }\end{array}$ \\
\hline $20 \%$ terendah & $80 \%$ lainnya & $\mu_{\mathrm{A}}=\mu_{\mathrm{B}}$ \\
$40 \%$ terendah & $60 \%$ lainnya & $\mu_{\mathrm{A}}=\mu_{\mathrm{B}}$ \\
$40 \%$ tertinggi & $60 \%$ lainnya & $\mu_{\mathrm{A}}=\mu_{\mathrm{B}}$ \\
$20 \%$ tertinggi & $80 \%$ lainnya & $\mu_{\mathrm{A}}=\mu_{\mathrm{B}}$ \\
\hline
\end{tabular}

Catatan: $\mu$ adalah rata variabel KMF atau KTF untuk masingmasing kelompok

Berdasarkan uji tersebut, jika hasil uji statistik menunjukkan hipotesis nul (Ho) diterima, maka secara umum dapat dikatakan bahwa tidak ada disparitas pada variabel KMF maupun KTF selama periode yang dianalisis. Sebaliknya, jika hasil uji statistik menunjukkan hipotesis nul (Ho) ditolak, maka secara umum dapat dikatakan terjadi disparitas pada variabel fiskal masing-masing. Untuk mengetahui seberapa besar disparitas yang terjadi, maka tergantung pada kelompok mana dari keempat kriteria tersebut hipotesis nul ditolak.

\section{HASIL DAN PEMBAHASAN}

\section{Kemandirian dan Ketergantungan Fiskal Kota/Kabupaten}

Dari tahun ke tahun perkembangan fiskal yang ditunjukkan oleh tingkat kemandirian dan ketergantungan fiskal pemerintah daerah kota/ kabupaten di Provinsi Jawa Tengah menunjukkan variasi yang cukup besar. Variasi tersebut menggambarkan bahwa kota/provinsi memiliki kemampuan berbeda-beda dalam meraih dan pendapatan asli daerah maupun dalam meraih dana transfer dari pemerintah pusat. Pada kenyataannya, kota/kabupaten memerlukan dana yang semakin besar untuk membiayai program-program pembangunannya. Sumber pembiayaan ini berasal dari dua sumber pokok, yaitu PAD dan dana perimbangan, yang bagian terbesarnya adalah Dana Alokasi Umum (DAU). Namun dalam perkembangan terakhir dana DAU memegang peranan sekitar 85 persen dari total kebutuhan pendapatan APBD. Jika belanja daerah lebih besar dari PAD dan dana perimbangan, maka APBD akan mengalami defisit yang pada umumnya dibiayai dengan SILPA dan utang. Oleh karena itu tinggi rendahnya PAD dan perimbangan, yang biasa disebut kapasitas fiskal, merupakan kunci pelaksanaan program pembangunan di daerah.

Ukuran kapasitas fiskal sebagai indikator kemampuan fiskal daerah dalam memenuhi kebutuhan belanja dapat dilihat dari besarnya rasio penjumlahan PAD dan dana transfer pemerintah pusat terhadap belanja daerah. Indikator lain atas kemampuan fiskal daerah dapat juga diperoleh dari rasio antara PAD terhadap belanja daerah, dikenal sebagai kemandirian fiskal daerah, sedangkan rasio antara dana transfer terhadap total belanja disebut ketergantungan fiskal.

Data-data yang menunjukkan tingkat kemandirian fiskal kabupaten/kota di provinsi Jawa Tengah dipaparkan pada Gambar 1, sedangkan perkembangan ketergantungan fiskal digambarkan pada Gambar 2. Dari data-data 
tersebut menunjukkan bahwa tingkat kemandirian fiskal kota dan kabupaten di Jawa Tengah sangat bervariasi. Secara garis besar ada enam kabupaten dan kota yang memiliki kemandirian fiskal terbesar dengan tingkat kemandirian hampir 25 persen dari total belanja. Ini berarti bahwa PAD kota dan kabupaten tersebut sekitar 25 persen porsi belanja total dapat dibiayai dari PAD.

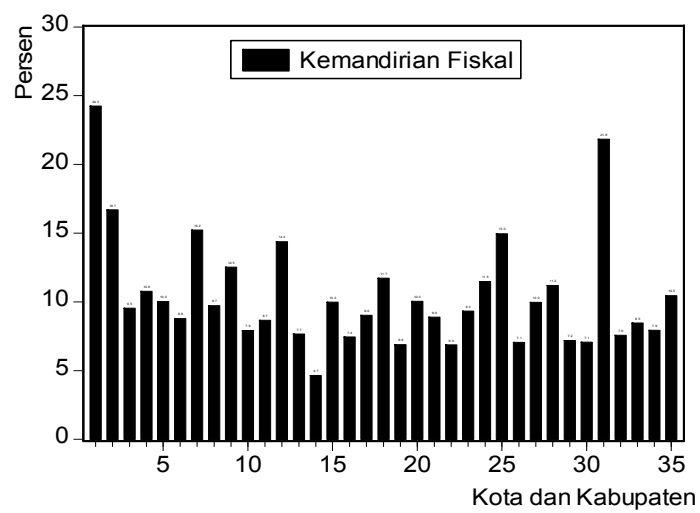

Gambar 1. Rata-Rata Kemandirian Fiskal Kota/ Kabupaten di Jawa Tengah Tahun 2007-2009

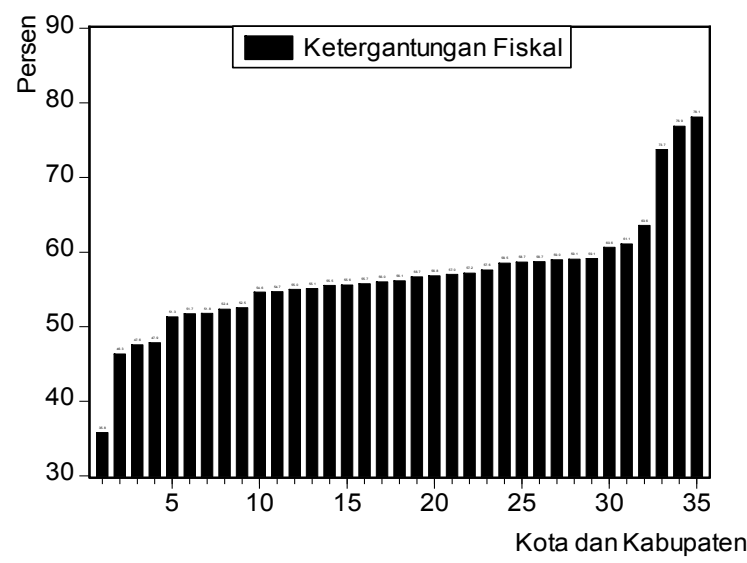

\section{Gambar 2. Rata-Rata Ketergantungan Fiskal Kota/Kabupaten di Jawa Tengah Tahun 2007-2009}

Perkembangan tingkat ketergantungan fiskal seperti dipaparkan pada Gambar 2 menunjukkan adanya dinamika yang moderat antar kota dan kabupaten di provinsi Jawa Tengah.
Dari data tersebut dapat diketahui hanya ada tiga kabupaten yang memiliki ketergantungan terbesar terhadap pemerintah pusat, yaitu dengan tingkat ketergantungan sekitar hampir 80 persen. Ini berarti semua kota dan kabupaten masih sangat tergantung kepada pemerintah pusat dalam membiayai belanja totalnya. Namun demikian ada satu kota yang memiliki ketergantungan fiskal cukup rendah dimana kurang dari 40 persen porsi dana transfer yang digunakan untuk pembiayaan pembangunan. Kondisi ini secara umum menuntut adanya peningkatan sumber-sumber pendapatan daerah yang berasal dari daerah itu sendiri yang masuk dalam PAD.

\section{Analisis Disparitas Kemandirian dan Ketergantungan fiskal}

Analisis disparitas dengan menggunakan metode dua uji beda rata-rata terhadap kemandirian fiskal untuk masing-masing tahun 2007, 2008 dan 2009 ditampilkan pada Tabel 2, Tabel 3 dan Tabel 4. Dari hasil analisis untuk data kemandirian fiskal tahun 2007 menunjukkan adanya perbedaan yang signifikan antara berbagai kelompok kemandirian fiskal dengan kelompok lainnya pada tahun tersebut (Tabel 2). Kelompok kota/kabupaten yang memiliki tingkat kemandirian fiskal 20 persen terendah ternyata memiliki rata-rata yang berbeda secara signifikan dengan rata-rata tingkat kemandirian fiskal kota/kabupaten lainnya. Kelompok kota/kabupaten yang memiliki tingkat kemandirian fiskal 40 persen terendah ternyata memiliki rata-rata yang berbeda secara signifikan dengan rata-rata tingkat kemandirian fiskal kota/kabupaten lainnya. Kelompok kota/kabupaten yang memiliki tingkat kemandirian fiskal 40 persen tertinggi ternyata juga memiliki rata-rata yang berbeda secara signifikan dengan rata-rata tingkat kemandirian fiskal kota/kabupaten lainnya. Kelompok kota/kabupaten yang memiliki tingkat kemandirian fiskal 20 persen tertinggi ternyata juga memiliki rata-rata yang berbeda secara signifikan dengan rata-rata tingkat kemandirian fiskal kota/kabupaten lainnya. Hasil ini memberikan implikasi adanya disparitas kemandirian fiskal yang kuat antarkota dan kabupaten di provinsi Jawa Tengah pada tahun tersebut. 
Tabel 2. Hasil Uji Beda Rata-Rata pada Variabel KMF Tahun 2007

\begin{tabular}{cccc}
\hline $\begin{array}{c}\text { Kelompok } \\
\text { (A) }\end{array}$ & $\begin{array}{c}\text { Diuji } \\
\text { Terhadap } \\
\text { Kelompok } \\
\text { (B) }\end{array}$ & $\begin{array}{c}\text { Nilai p- } \\
\text { Value } \\
\text { pada } \\
\text { Hasil } \\
\text { Uji t }\end{array}$ & $\begin{array}{c}\text { Arti Hasil } \\
\text { Uji-t }\end{array}$ \\
\hline $\begin{array}{c}20 \% \\
\text { terendah } \\
40 \%\end{array}$ & $80 \%$ lainnya & $0,031^{\mathrm{a}}$ & $\begin{array}{c}\text { Ada } \\
\text { perbedaan } \\
\text { Ada }\end{array}$ \\
$\begin{array}{c}\text { terendah } \\
40 \%\end{array}$ & $60 \%$ lainnya & $0,056^{\mathrm{b}}$ & $\begin{array}{c}\text { perbedaan } \\
\text { Ada }\end{array}$ \\
$\begin{array}{c}\text { tertinggi } \\
20 \%\end{array}$ & $60 \%$ lainnya & $0,082^{\mathrm{b}}$ & $\begin{array}{c}\text { perbedaan } \\
\text { Ada }\end{array}$ \\
tertinggi & $80 \%$ lainnya & $0,025^{\mathrm{a}}$ & \begin{tabular}{c} 
perbedaan \\
\hline
\end{tabular}
\end{tabular}

Catatan: a,b, adalah masing-masing signifikan untuk a $=5$ dan $10 \%$

Hasil analisis dengan menggunakan data kemandirian fiskal untuk tahun 2008 ditampilkan pada Tabel 3.

Tabel 3. Hasil Uji Beda Rata-Rata pada Variabel KMF Tahun 2008

\begin{tabular}{|c|c|c|c|}
\hline $\begin{array}{l}\text { Kelompok } \\
\text { (A) }\end{array}$ & $\begin{array}{c}\text { Diuji } \\
\text { Terhadap } \\
\text { Kelompok } \\
\text { (B) } \\
\end{array}$ & $\begin{array}{l}\text { Nilai p- } \\
\text { value } \\
\text { pada } \\
\text { hasil uji t }\end{array}$ & $\begin{array}{c}\text { Arti Hasil } \\
\text { Uji-t }\end{array}$ \\
\hline $\begin{array}{c}20 \% \\
\text { terendah }\end{array}$ & $80 \%$ lainnya & $0,031^{\mathrm{a}}$ & $\begin{array}{c}\text { Ada } \\
\text { perbedaan }\end{array}$ \\
\hline $\begin{array}{c}40 \% \\
\text { terendah }\end{array}$ & $60 \%$ lainnya & $0,075^{b}$ & $\begin{array}{c}\text { Ada } \\
\text { perbedaan }\end{array}$ \\
\hline $\begin{array}{l}40 \% \\
\text { tertinggi }\end{array}$ & $60 \%$ lainnya & $0,088^{b}$ & $\begin{array}{c}\text { Ada } \\
\text { perbedaan }\end{array}$ \\
\hline $\begin{array}{c}20 \% \\
\text { tertinggi }\end{array}$ & 80\% lainnya & $0,015^{b}$ & $\begin{array}{c}\text { Ada } \\
\text { perbedaan }\end{array}$ \\
\hline
\end{tabular}

Catatan: a,b, adalah masing-masing signifikan untuk a $=5$ dan $10 \%$

Dari hasil analisis menunjukkan adanya perbedaan yang signifikan antara berbagai kelompok kemandirian fiskal dengan kelompok lainnya pada tahun tersebut. Kelompok kota/ kabupaten yang memiliki tingkat kemandirian fiskal 20 persen dan 40 persen terendah ternyata memiliki rata-rata yang berbeda secara signifikan dengan rata-rata tingkat kemandirian fiskal kota/kabupaten lainnya. Kelompok kota/ kabupaten yang memiliki tingkat kemandirian fiskal 40 persen dan 20 persen tertinggi ternyata juga memiliki rata-rata yang berbeda secara signifikan dengan rata-rata tingkat kemandirian fiskal kota/kabupaten lainnya. Hasil ini memberikan implikasi adanya disparitas kemandirian fiskal yang kuat antarkota dan kabupaten di provinsi Jawa Tengah pada tahun tersebut.

Dari hasil analisis untuk data kemandirian fiskal tahun 2009 menunjukkan adanya perbedaan yang signifikan antara berbagai kelompok kemandirian fiskal dengan kelompok lainnya pada tahun tersebut. Kelompok kota/kabupaten yang memiliki tingkat kemandirian fiskal 20 persen dan 40 persen terendah serta kelompok kota/kabupaten yang memiliki tingkat kemandirian fiskal 40 persen dan 20 persen tertinggi memiliki rata-rata yang berbeda secara signifikan dengan rata-rata tingkat kemandirian fiskal kota/kabupaten lainnya. Hasil ini juga menggambarkan adanya disparitas kemandirian fiskal yang semakin kuat antarkota dan kabupaten di provinsi Jawa Tengah pada tahun tersebut.

Tabel 4. Hasil Uji Beda Rata-Rata pada Variabel KMF Tahun 2009

\begin{tabular}{|c|c|c|c|}
\hline $\begin{array}{c}\text { Kelompok } \\
\text { (A) }\end{array}$ & $\begin{array}{c}\text { Diuji } \\
\text { Terhadap } \\
\text { Kelompok } \\
\text { (B) } \\
\end{array}$ & $\begin{array}{l}\text { Nilai p- } \\
\text { value } \\
\text { pada } \\
\text { hasil uji t }\end{array}$ & $\begin{array}{c}\text { Arti Hasil } \\
\text { Uji-t }\end{array}$ \\
\hline $\begin{array}{c}20 \% \\
\text { terendah }\end{array}$ & $80 \%$ lainnya & $0,011^{\mathrm{a}}$ & $\begin{array}{c}\text { Ada } \\
\text { perbedaan }\end{array}$ \\
\hline $\begin{array}{l}40 \% \\
\text { terendah }\end{array}$ & $60 \%$ lainnya & $0,026^{a}$ & $\begin{array}{c}\text { Ada } \\
\text { perbedaan }\end{array}$ \\
\hline $\begin{array}{l}40 \% \\
\text { tertinggi }\end{array}$ & $60 \%$ lainnya & $0,032^{a}$ & $\begin{array}{c}\text { Ada } \\
\text { perbedaan }\end{array}$ \\
\hline $\begin{array}{c}20 \% \\
\text { tertinggi }\end{array}$ & $80 \%$ lainnya & $0,015^{a}$ & $\begin{array}{c}\text { Ada } \\
\text { perbedaan }\end{array}$ \\
\hline
\end{tabular}

Catatan: a adalah masing-masing signifikan untuk $a=5$

Untuk analisis disparitas dengan menggunakan metode dua uji beda rata-rata terhadap ketergantungan fiskal untuk masing-masing tahun 2007, 2008 dan 2009 ditampilkan pada Tabel 5, Tabel 6 dan Tabel 7. Dari hasil analisis untuk data ketergantungan fiskal tahun 2007 menunjukkan adanya perbedaan yang signifi- 
kan antara kelompok kota/kabupaten yang memiliki tingkat ketergantungan 20 persen tertinggi dan 20 persen terendah dengan kelompok lainnya (Tabel 5). Kelompok kota/kabupaten yang memiliki tingkat ketergantungan fiskal 40 persen terendah ternyata memiliki rata-rata yang tidak berbeda secara signifikan dengan rata-rata tingkat ketergantungan fiskal kota/ kabupaten lainnya. Adapun kelompok kota/kabupaten yang memiliki tingkat ketergantungan fiskal 40 persen tertinggi ternyata juga memiliki rata-rata yang tidak berbeda secara signifikan dengan rata-rata tingkat ketergantungan fiskal kota/kabupaten lainnya. Hasil ini memberikan implikasi adanya disparitas ketergantungan fiskal yang rendah antarkota dan kabupaten di provinsi Jawa Tengah pada tahun tersebut.

Tabel 5. Hasil Uji Beda Rata-Rata pada Variabel KTF Tahun 2007

\begin{tabular}{|c|c|c|c|}
\hline $\begin{array}{c}\text { Kelompok } \\
\text { (A) }\end{array}$ & $\begin{array}{c}\text { Diuji } \\
\text { Terhadap } \\
\text { Kelompok } \\
\text { (B) }\end{array}$ & $\begin{array}{l}\text { Nilai p- } \\
\text { value } \\
\text { pada } \\
\text { hasil uji t }\end{array}$ & $\begin{array}{c}\text { Arti Hasil } \\
\text { Uji-t }\end{array}$ \\
\hline $\begin{array}{c}20 \% \\
\text { terendah }\end{array}$ & $80 \%$ lainnya & $0,091^{b}$ & $\begin{array}{c}\text { Ada } \\
\text { perbedaan }\end{array}$ \\
\hline $\begin{array}{l}40 \% \\
\text { terendah }\end{array}$ & $60 \%$ lainnya & 0,116 & $\begin{array}{l}\text { Tidak ada } \\
\text { perbedaan }\end{array}$ \\
\hline $\begin{array}{c}40 \% \\
\text { tertinggi }\end{array}$ & $60 \%$ lainnya & 0,132 & $\begin{array}{l}\text { Tidak ada } \\
\text { perbedaan }\end{array}$ \\
\hline $\begin{array}{c}20 \% \\
\text { tertinggi }\end{array}$ & 80\% lainnya & $0,085^{b}$ & $\begin{array}{c}\text { Ada } \\
\text { perbedaan }\end{array}$ \\
\hline
\end{tabular}

Catatan: $b$ adalah masing-masing signifikan untuk $a=10 \%$

Hasil analisis untuk 2008 ditampilkan pada Tabel 6. Dari hasil analisis untuk data ketergantungan fiskal tahun tersebut menunjukkan hasil yang tidak berbeda dengan tahun sebelumnya. Kelompok kota/kabupaten yang memiliki tingkat ketergantungan 20 persen tertinggi dan 20 persen terendah memiliki ketergantungan fiskal yang signifikan dengan kelompok lainnya. Kelompok kota/kabupaten yang memiliki tingkat ketergantungan fiskal 40 persen terendah dan 40 persen tertinggi memiliki rata-rata yang tidak berbeda secara signifikan dengan ratarata tingkat ketergantungan fiskal kota/kabupaten lainnya. Hasil ini juga memberikan implikasi adanya disparitas ketergantungan fiskal yang rendah antarkota dan kabupaten di provinsi Jawa Tengah pada tahun tersebut.

Tabel 6. Hasil Uji Beda Rata-Rata pada Variabel KTF Tahun 2008

\begin{tabular}{|c|c|c|c|}
\hline $\begin{array}{c}\text { Kelompok } \\
\text { (A) }\end{array}$ & $\begin{array}{c}\text { Diuji } \\
\text { Terhadap } \\
\text { Kelompok } \\
\text { (B) } \\
\end{array}$ & $\begin{array}{l}\text { Nilai p- } \\
\text { value } \\
\text { pada } \\
\text { hasil uji t }\end{array}$ & $\begin{array}{c}\text { Arti Hasil } \\
\text { Uji-t }\end{array}$ \\
\hline $\begin{array}{c}20 \% \\
\text { terendah }\end{array}$ & $80 \%$ lainnya & $0,054^{b}$ & $\begin{array}{c}\text { Ada } \\
\text { perbedaan }\end{array}$ \\
\hline $\begin{array}{l}\quad 40 \% \\
\text { terendah }\end{array}$ & $60 \%$ lainnya & 0,226 & $\begin{array}{l}\text { Tidak ada } \\
\text { perbedaan }\end{array}$ \\
\hline $\begin{array}{l}40 \% \\
\text { tertinggi }\end{array}$ & $60 \%$ lainnya & 0,182 & $\begin{array}{l}\text { Tidak ada } \\
\text { perbedaan }\end{array}$ \\
\hline $\begin{array}{c}20 \% \\
\text { tertinggi }\end{array}$ & $80 \%$ lainnya & $0,067 \mathrm{~b}$ & $\begin{array}{c}\text { Ada } \\
\text { perbedaan }\end{array}$ \\
\hline
\end{tabular}

Catatan: $b$ adalah masing-masing signifikan untuk $a=$ an $10 \%$

Untuk data ketergantungan fiskal untuk 2009 seperti ditampilkan pada Tabel 7 memberikan hasil yang berbeda dengan analisis tahun sebelumnya.

Tabel 7. Hasil Uji Beda Rata-Rata pada Variabel KTF Tahun 2009

\begin{tabular}{|c|c|c|c|}
\hline $\begin{array}{c}\text { Kelompok } \\
\text { (A) }\end{array}$ & $\begin{array}{c}\text { Diuji } \\
\text { Terhadap } \\
\text { Kelompok } \\
\text { (B) }\end{array}$ & $\begin{array}{c}\text { Nilai p- } \\
\text { value } \\
\text { pada } \\
\text { hasil uji t }\end{array}$ & $\begin{array}{c}\text { Arti Hasil } \\
\text { Uji-t }\end{array}$ \\
\hline $\begin{array}{c}20 \% \\
\text { terendah }\end{array}$ & $80 \%$ lainnya & 0,133 & $\begin{array}{l}\text { Tidak ada } \\
\text { perbedaan }\end{array}$ \\
\hline $\begin{array}{c}40 \% \\
\text { terendah }\end{array}$ & $60 \%$ lainnya & 0,126 & $\begin{array}{l}\text { Tidak ada } \\
\text { perbedaan }\end{array}$ \\
\hline $\begin{array}{l}40 \% \\
\text { tertinggi }\end{array}$ & $60 \%$ lainnya & 0,163 & $\begin{array}{l}\text { Tidak ada } \\
\text { perbedaan }\end{array}$ \\
\hline $\begin{array}{c}20 \% \\
\text { tertinggi }\end{array}$ & $80 \%$ lainnya & $0,081^{b}$ & $\begin{array}{c}\text { Ada } \\
\text { perbedaan }\end{array}$ \\
\hline
\end{tabular}

Catatan: $b$, adalah masing-masing signifikan untuk $a=10 \%$

Dari hasil analisis untuk data ketergantungan fiskal tahun tersebut menunjukkan ti- 
dak adanya perbedaan yang signifikan antara berbagai kelompok ketergantungan fiskal dengan kelompok lainnya pada tahun tersebut kecuali untuk kelompok pada kota/kabupaten yang memiliki tingkat ketergantungan 20 persen tertinggi dengan kelompok lainnya. Kelompok kota/kabupaten yang memiliki tingkat ketergantungan fiskal 20 persen terendah, 40 persen terendah dan 40 persen tertinggi memiliki rata-rata yang tidak berbeda secara signifikan dengan rata-rata tingkat ketergantungan fiskal kota/kabupaten lainnya. Hasil ini memberikan implikasi hampir tidak adanya disparitas ketergantungan fiskal yang rendah antarkota dan kabupaten di provinsi Jawa Tengah pada tahun tersebut.

Dari hasil analisis terhadap data kemandirian dan ketergantungan fiskal menunjukkan tingkat disparitas yang berbeda (Tabel 7). Untuk analisis disparitas kemandirian fiskal menunjukkan adanya disparitas yang tinggi dan cenderung konstan selama tiga tahun yang diamati. Adapun untuk analisis disparitas berdasarkan data ketergantungan fiskal menunjukkan tidak adanya perbedaan yang signifikan antarberbagai kelompok ketergantungan fiskal dengan kelompok lainnya. Hal ini menunjukkan adanya kecenderungan adanya disparitas ketergantungan fiskal yang relatif rendah antarkota/kabupaten selama tiga tahun. Berdasarkan pada uji statistik selama tiga tahun menunjukkan nilai p-value yang semakin besar, yang berarti adanya pergerakan terjadinya penurunan tingkat disparitas ketergantungan fiskal. Hasil ini memberikan implikasi bahwa kota dan kabupaten di provinsi Jawa Tengah secara terus menerus memiliki kemandirian fiskal yang sangat bervariasi namun cenderung memiliki ketergantungan fiskal yang hampir sama. Kondisi ini berdampak pada rendahnya diskresi pemerintah daerah dalam menyusun perencanaan dan pelaksanaan pembangunan di daerah.

\section{SIMPULAN}

Meningkatnya kewenangan daerah kota dan kabupaten untuk menyelenggarakan pembangunan daerah diperlukan sumber dana yang semakin besar pula. Di sisi lain sumber keuangan daerah kota dan kabupaten yang berasal dari Pendapatan Asli Daerah masih relatif rendah dibandingkan kebutuhan belanja daerah sehingga menimbulkan tingkat kemandirian fiskal yang rendah serta tingkat ketergantungan fiskal yang tinggi. Walaupun terjadi peningkatan penerimaan daerah, namun peningkatan tersebut tidak sebesar peningkatan pengeluaran pemerintah sehingga semakin lama penerimaan daerah tidak mampu memenuhi kebutuhan dana pemerintah untuk menutup belanja pemerintah daerah. Pemerintah menghadapi kekurangan dana untuk memenuhi kebutuhan belanja pemerintah guna memenuhi tuntutan pembangunan maupun belanja publik.

Peningkatan pengeluaran pemerintah telah mengakibatkan penurunan kemandirian fiskal, karena rasio penerimaan daerah terhadap belanja total semakin rendah. Bahkan variabel yang mencerminkan kemampuan keuangan negara dalam membiayai pengeluaran tersebut terus menerus mengalami penurunan. Selain itu antarkota dan kabupaten di provinsi Jawa Tengah memiliki disparitas yang tinggi pada kemandirian fiskal. Adapun untuk indikator ketergantungan fiskal memiliki tingkat disparitas yang relatif rendah. Oleh karena itu untuk menjaga terjaminnya pelaksanaan pembangunan dan pelayanan publik di daerah perlu dilakukan kebijakan peningkatan kemandirian fiskal di daerah. Hal ini bertujuan agar pemerintah daerah dapat meningkatkan aktivitas ekonomi yang dapat menjadi sumbersumber penerimaan daerah.

Tingkat ketergantungan fiskal antarkota/ kabupaten di Jawa Tengah juga menunjukkan adanya disparitas yang sangat walaupun dalam taraf yang relatif rendah. Hal ini menunjukkan adanya ketidakseimbangan kemampuan keuangan antarkota/kabupaten di provinsi tersebut. Hal ini tentu saja akan menimbulkan perbedaan kemampuan dalam pembangunan dan pelayanan publik. Kota dan kabupaten yang umumnya sudah lebih maju justru memiliki kemampuan keuangan yang lebih besar daripada daerah lainnya sehingga implikasi diasparitas kemadirian dan ketergantungan fiskal akan berdampak pada disparitas kualitas pelayanan publik. Melihat fenomena ini, maka 
perlu diambil kebijakan untuk meningkatkan kemampuan keuangan di kabupaten dengan cara peningkatan transfer kepada kota dan kabupaten yang memiliki ketergantungan fiskal tinggi.

Untuk meningkatkan kemampuan keuangan pemerintah kota dan kabupaten, maka selain peningkatan penerimaan pajak daerah juga dapat dilakukan dengan perubahan kebijakan peningkatan transfer fiskal dari pemerintah pusat kepada daerah. Pemerintah perlu membuat formula baru transfer fiskal dengan mempertimbangan berbagai variabel ekonomi, fiskal dan demografi bagi kota dan kabupaten. Selain itu juga perlu desain transfer fiskal yang mempertimbangkan tingkat ketergantungan fiskal daerah. Kebijakan praktis yang perlu dilakukan adalah: (1) Revisi UU No 33 Tahun 2004 tentang formula penetapan dana transfer, khsusunya DAU dengan memasukkan aspek ketergantungan fiskal sebagai penentu dana transfer dalam bobot yang lebih besar; (2) Peningkatan besaran dana trasfer fiskal ke daerah yang besarnya 26 persen total penerimaan APBN untuk meningkatkan kapasitas fiskal di daerah; (4) Perlunya peningkatan pemerataan transfer fiskal dengan mempertimbangkan ketergantungan fiskal pada masing-masing daerah kota maupun kabupaten dalam satu provinsi; (5) Untuk mendorong fungsi perimbangan dari hubungan fiskal pusat-daerah, maka sebagian dana DAU harus dialokasikan untuk belanja langsung sehingga dapat berdampak pada kegiatan pembangunan daerah; (6) Pemerintah seharusnya mengurangi disparitas jumlah dana transfer untuk menghindari kesenjangan anggaran antardaerah kota dan kabupaten; (7) Pemerintah daerah perlu melakukan pergeseran dari alokasi anggaran administrasi yang terlalu besar menuju penerapan kebijakan pemberian layanan masyarakat dan pengembangan bisnis serta kegiatan ekonomi masyarakat sehingga dapat meningkatkan potensi pajak daerah.

\section{DAFTAR PUSTAKA}

Ahmed, S. and Greene, K.V. 2000. Is The Median Voter A Clear Cut Winner? Com- paring The Median Voter Theory and Competing Theory in Explaining Local Government Spending. Public Choice, 102: 8-24.

Ananda, Candra Fajri. 2002. Problems of The Implementation of Fiscal Decentralization in Regional Autonomy: The Case of Malang Municipality and Trenggalek District. Laporan Penelitian Fakultas Ekonomi, Universitas Brawijaya, Malang.

Berument, H. 1994. Political Parties and Government Financing: Empirical Evidence for Industrialized Coutries. Southern Economic Journal, 61: 511-518.

Haris, S. 2005. Desentralisasi dan Otonomi Daerah: Desentralisasi, Demokratisasi \& Akuntabilitas Pemerintah Daerah. Jakarta: LIPI Press.

Hofman, B., Kadjatmiko, Kaiser, K., dan Sjahrir, B.S. 2006. Evaluating Fiscal Equalization in Indonesia. World Bank Policy Research Working Paper 3911, May.

Hondroyiannis, G., dan Papapetrue, E. 2001. An Investigation of the Public Deficit and Government Spending Relationship: Evidence for Greece. Public Choice No. 107: $169-182$.

Kurnia, A. S. 2006. Model Pengukuran Kinerja dan Efisiensi Sektor Publik Metode Free Disposable Hull (FDH). Jurnal Ekonomi Pembangunan, Volume 11, No. 1, 1-20. Yogyakarta: Ekonisia FE UII.

Merifield, J. 2000. State Government Expenditure Determinants and Tax Revenue Determinants Revissited. Public Choice, 102: 25-50.

Nasara, S. 2010. Pemerataan Antardaerah Sebagai Tantangan Utama Transformasi Struktural Pembangunan Ekonomi Indonesia Masa Depan. Pidato Pengukuhan Guru Besar dalam Bidang Ilmu Ekonomi, Fakultas Ekonomi, Universitas Indonesia, 10 Maret 2010.

OECD. 2002. Fiscal Sustainability: the Contribution of Fiscal Rules. in: OECD Economic Outlook 72, pp. 117-136. Paris: Organiza- 
tion for Economic Cooperation and Development.

Pertiwi, Lela Dina. 2006. Efisiensi Pengeluaran Pemerintah di Sektor Pendidikan dan Kesehatan: Studi Kasus di Jawa TengahTahun 1999 dan 2002. Skripsi Sarjana (Tidak dipublikasikan). Yogyakarta: Fakultas Ekonomi, Universitas Islam Indonesia,.

Salam, A. 2005. Menimbang Kembali Kebijakan Otonomi Daerah. Jakarta: LIPI Press, Anggota IKAPI.

Schuvnecht, Ludger. 2000. Fiscal Policy Cycles and Public Expenditure in Developing Countries. Public Choice, 102: 115-130.

Sebayang, A. F. 2005. Kinerja Kebijakan Fiskal Daerah di Indonesia Pasca Krisis. Jurnal Ekonomi Pembangunan, Volume 10, No. 3, 203-214. Yogyakarta: Ekonisia FE UII.

Simanjuntak, R.A., dan Hidayanto, D. 2005.
Dana Alokasi Umum di Masa Depan, dalam Dana Alokasi Umum: Konsep, Hambatan dan Prospek Di Era Otonomi Daerah. Jakarta: LPEM Universitas Indonesia.

Sumiyarti dan Imamy, A. F. 2005. Analisis Pengaruh Perimbangan Pusat-Daerah Terhadap Perekonomian Kota Depok. Media Ekonomi, Vol 11, No. 2, 113-128. Jakarta: LPFE.

Tanzi, V. \& Schuknecht, L. 2000. Public Spending in the 20th Century. Cambridge: Cambridge University Press.

Tarigan, A. 2005. Urgensi Penguatan Keuangan Daerah, Suatu Tinjauan Terhadap Regulasi Daerah dan Implikasinya dalam Penyediaan Pelayanan Publik. Perencanaan Pembangunan, Edisi 04/IX/Jul-Sept. Yogyakarta: BPFE, UGM. 


\section{D}

disparitas fiskal, 56, 58, 59, 60

\section{$\mathbf{F}$}

fiscal capacity, 56

fiscal dependency, 56

fiscal disparities, 56

\section{K}

kemampuan fiskal, 56, 57, 60

ketergantungan fiskal, 56, 59, 60, 61, 62, 63, 64, 65

$\mathbf{P}$

pembangunan daerah, 56, 59, 64, 65

$\mathbf{R}$

regional development, 56 